\title{
Genentech falls at the last fence in race to market heart drug
}

Washington

THE US Food and Drug Administration (FDA) has strengthened its position as the agency pharmaceutical and biotechnology companies most love to hate with a surprise recommendation from an advisory committee that a heart drug, tissue plasminogen activator, is not yet ready for the market. The crowded hearing at which the announcement was made ended in confusion with representatives of Genentech Inc., the drugs manufacturer, demanding a fair deal, and stock analysts rushing for the door, pulling portable phones from their briefcases as they went. Almost $\$ 1,000$ million was wiped off the value of Genentech's stocks and other biotechnology companies were dragged down with it .

Tissue plasminogen activator (TPA) has not been a particularly controversial drug. It is found naturally in the body and activates systems that dissolve blood clots. Genentech's clinical trials show that it does so more effectively than streptokinase, a drug that has been on the market for years and to which the FDA has just given approval for a more direct, intravenous administration procedure. Genentech's presumption was that, following as they were in the trail blazed by streptokinase, evidence of the efficacy of TPA in dissolving clots in the heart would necessarily imply that it would help clear the blocked arteries that cause heart attacks. Clcarly, the company believed it had been encouraged in this view by the FDA's Office of Biologics, Research and Reviews.

The FDA's cardiovascular and renal advisory committee thought differently. Perhaps encouraged by a magnificent Italian study for streptokinase, dealt with on the same day, that involved almost 12,000 patients in coronary clinics and showed that the mortality rate was reduced, the committee said that evidence of TPA's clinical effectiveness in prolonging life was needed. The recommendation, although not yet officially accepted by the FDA, sets back Genetech's plans and presents them with a big problem. Clinical evidence that TPA prolongs the life of heart attack patients could only be obtained by trials in which some patients received the drug and others a placebo. But given the evidence now available that TPA clears blocked arteries, most doctors would find the experiment unethical.

The FDA is under some pressure. If time-consuming trials are now begun that eventually prove TPA's effectiveness in helping overcome heart attacks, there is bound to be criticism that the drug was kept off the market for too long. Who will then be to blame for the delay? Ugly (but unsubstantiated) rumours already abound that part of the reason for the FDA committee's tough stand was that they were under pressure to show who was boss. But at the same time, many industry observers think Genentech was naive to have gone to the hearing without at least a prepared answer to the obvious question of whether dissolving blood clots helps heart-attack victims. The most likely outcome is that the FDA will accept evidence showing that TPA improves left-ventricular function and not demand survival data. But nobody at the FDA or on the advisory committee is prepared to make a statement. That is perhaps not surprising given that the market for TPA could be worth thousands of millions of dollars. Other biotechnology companies, behind Genentech in the race to market TPA, welcome every delay as a chance to catch up. No US patent has been awarded for TPA, and see below for details of its problems elsewhere.

Alun Anderson

\section{Indo-French science cooperation begins}

\section{New Delhi}

INDIA and France have demonstrated their wish to boost cooperation in science by formally establishing the Indo-French Centre for Promotion of Advanced Research (IFCPAR) in New Delhi, to promote joint research in advanced areas of both fundamental and applied research.

An Indian scientist will direct the centre, which is to be managed by a governing body of five members each from India and France. The cost will be shared, and an eight-member council of an equal number of French and Indian scientists will consider research proposals and training. Although it has some commercial technical collaborations, France has been lagging behind other Western countries in bilateral cooperation with Indian institutions.

At the first meeting of the governing body last week, the centre identified five areas for cooperation: mathematics, informatics, optics and opto-electronics, energy and biotechnology.

K.S. Jayaraman

\section{TPA patent battle rages in United Kingdom}

\section{London}

ToP guns from both sides of the Atlantic are lining up in London's High Court this week, ready for the opening salvos of Britain's first major biotechnology patent battle.

The British pharmaceutical firm Wellcome is challenging the patent held by USbased Genentech on human tissue plasminogen activator (TPA), a substance that holds great promise for treatment of cardiovascular diseases (see above). The patent, issued in February 1986, is very comprehensive, covering "human TPA, pharmaceutical compositions containing it, processes for making it, and DNA and transformed cell intermediates thereof".

It is this breadth that is opposed by Wellcome, as well as the central issue of novelty. Using recombinant DNA technology to develop human TPA, Wellcome's lawyer told the court, was "a matter of routine" once it was accepted that the substance was needed in quantity. "It is a highly desirable product, so the motive is particularly high," the lawyer said. "You mean the profit motive," the judge replied, adding, "without that we shouldn't all be here today".

Both companies are clearly willing to pump all necessary resources into the court case, which is expected to continue for three weeks, with banks of scientists and mountains of reports cramming the courtroom. It is widely seen as a test case for the patentability of the products of biotechnology.

In the opening arguments, Wellcome's lawyer pointed out that the patent covers "all forms of TPA except that found naturally in humans, and all ways of making it, known and unknown." He told the court, "TPA is not an invented product - but even if it is, it is quite wrong to claim (in a patent) every other way to get it. Even if you find a new way, there is no way you should have a patent on the old way." $\mathrm{He}$ said that the patent would give Genentech rights on the substance for 20 years.

Wellcome argues that standard geneticengineering approaches would have been able to clone a gene encoding TPA at the time the patent was applied for in $\mathbf{1 9 8 3}$, although not necessarily by the same route taken by Genentech.

Genentech is expected to argue that using mammalian cells instead of the usual bacterial cells is an innovation that classifies as an invention when company lawyers begin presenting their case next week. Evidence will also cover the difficulties of handling messenger RNA.

Wellcome told the court that the patent is already being infringed. It is thought that at least 30 biotechnology companies are making TPA, although no one has started marketing it yet. Genentech and its European partner Dr Karl Thomae GmbH, subsidiary of Boehringer Ingelheim, have a major investment in plant, and WelGen, a partnership of Wellcome and Genetics Institute, plan to open a TPA plant by 1989 . Scientists are already working on second-generation products, and waiting for the outcome of the case.

Kathy Johnston 